\title{
A volta da realidade das margens ${ }^{1}$ \\ Paulo Roberto Tonani do Patrocínio ${ }^{2}$
}

$\mathrm{Na}$ abertura do ensaio 18 de Brumário de Luís Bonaparte, Karl Marx apresenta a célebre frase que propõe uma leitura dos acontecimentos enquanto fenômenos cíclicos ao afirmar que: "Hegel observa em uma de suas obras que todos os fatos e personagens de grande importância na história do mundo ocorrem, por assim dizer, duas vezes. E esqueceu-se de acrescentar: a primeira vez como tragédia, a segunda como farsa". A referência à frase de Marx se faz necessária para evocar não a adjetivação proposta pelo autor para classificar os fatos e personagens históricos, mas, sim, para utilizar a sua percepção acerca da circularidade dos eventos. Por esse ponto de vista, interessa-me essa possibilidade de leitura do tempo, na qual é destacado o seu processo cíclico e a realização de um movimento de retorno. Talvez a imagem que melhor defina a afirmação de Marx não seja o círculo, e sim a espiral. Posto que os eventos não somente se repetem, mas são repetidos em diferença, produzindo uma espécie de oscilação na forma de caracterização dos fatos.

Em Tal Brasil, qual romance?, Flora Süssekind utiliza como referência a mesma frase de Marx para investigar os muitos retornos do naturalismo na história da literatura brasileira, buscando observar o mesmo movimento circular não apenas na passagem dos fatos e na construção de personagens históricos de grande importância, mas, igualmente, "alguns fatos estéticos, cuja ocorrência talvez não possa ser limitada a apenas duas vezes" (Süssekind, 1984, p. 40). Seguindo os passos de Flora Süssekind, proponho um movimento de leitura semelhante, com a diferença que, ao utilizar como ponto de partida uma concepção cíclica do tempo, busco empregá-la como referência para uma leitura dos muitos retornos do realismo. Desta forma, meu olhar segue amparado na análise produzida por Karl Erik Schøllhammer, em Fiç̧ão brasileira contemporânea (2009):

Ao longo do século XX, o realismo fez seu retorno sob diferentes formas - surrealismo, realismo fantástico, realismo regional, rea-

\footnotetext{
${ }^{1}$ Este ensaio é parte do projeto de pesquisa "A representação de territórios marginais na literatura brasileira”, desenvolvido com o financiamento da Fundação Carlos Chagas Filho de Amparo à Pesquisa do Estado do Rio de Janeiro (Faperj).

${ }^{2}$ Doutor em Estudos da Literatura pela Pontíficia Universidade Católica do Rio de Janeiro (PUC-Rio), Rio de Janeiro, Brasil. Atualmente desenvolve pesquisa de Pós-Doutorado na PUC-Rio, com o projeto "A representação de territórios marginais na literatura brasileira”, financiado pela Faperj. E-mail: paulotonani@gmail.com
} 
lismo mágico, new realism e hiper-realismo, para citar apenas alguns -, definidas, principalmente, pela diferença que estabeleciam com o realismo histórico do século XIX. (p. 53)

O exame de Schøllhammer é oportuno não somente por identificar a permanência do realismo ao longo do século $X X$, mas, principalmente, por colocar em relevo que tal movimento operado se baseia em um constante exercício estético que produz uma distinção frente ao modelo clássico. É traçada uma espiral, produzindo um efeito de expansão que parte de um único eixo. O modelo clássico do realismo histórico do século XIX serviu como ponto de partida, mas na observação da retomada do movimento, a cada volta realizada, é facilmente constatado o alargamento da experiência estética, que se expande e distancia do modelo. Dessa forma, os principais elementos estéticos do realismo do século XIX, sobretudo a descrição minuciosa dos ambientes, que apontavam para a busca de um "efeito de real", como caracterizou Roland Barthes ${ }^{3}$, passam a ser ressignificados e articulados a partir de uma nova configuração de realismo. Este novo modelo, na avaliação de Vera Lúcia Follain de Figueiredo,

voltou-se, reflexivamente, para a indagação do próprio sentido de narrar, desviando-se dos paradigmas do "bem narrar" - a incoerência da própria realidade levaria à rejeição das convenções realistas, que enfatizavam o caráter referencial da linguagem. (2010, p. 73)

A indagação do sentido de narrar aponta para a problematização acerca da linguagem frente ao real, produzindo novos procedimentos e, nesta perspectiva, resultando no abandono da matriz do realismo clássico. Torna-se oportuno cotejar tais estéticas, colocando em atrito os procedimentos contemporâneos em diálogo com o modelo do século XIX, conforme procedeu Beatriz Jaguaribe, no ensaio "Ficções do real: notas sobre as estéticas do realismo e pedagogias do olhar na América Latina contemporânea", ao observar que:

As novas estéticas realistas não repetem, necessariamente, o cânone das imagens e narrativas realistas do passado. Assim, as descrições detalhadas do ambiente que pautavam o romance realista do século XIX são muitas vezes preteridas em prol de uma prosa ágil que delineia o personagem e seu mundo através da fala ou da ação. O ponto

\footnotetext{
${ }^{3}$ Na leitura de Roland Barthes (2004b), o "efeito de real” nos romances do realismo do século XIX é alcançado no texto literário a partir da construção de uma linguagem centrada na descrição de detalhes de ambientação que do ponto de vista da estrutura da obra são irrelevantes e supérfluas para o enredo, mas, por outro lado, são fundamentais para conferirem ao texto uma verossimilhança realista.
}

58 estudos de literatura brasileira contemporânea, n.39, jan./jun. 2012, p. 57-75 
de vista onisciente em terceira pessoa que conferia autoridade ao narrador realista do século XIX é também muitas vezes substituído por uma narrativa subjetiva em primeira pessoa visando intensificar a verossimilhança e o apelo empático. (Jaguaribe, 2010, p. 8)

Mesmo que situado no início da espiral, o realismo do século XIX acaba por ser negligenciado enquanto referente e passa a ser substituído por novos empreendimentos estéticos. A busca pelo real permanece, mas, como destaca Schøllhammer, "os novos realistas querem provocar efeitos de realidade por outros meios" (Schøllhammer, 2009, p. 54). Ou seja, a origem acaba por ser apagada e em seu lugar surge um experimento formado pelo desejo de diferença frente ao exemplo.

É com essa orientação que proponho tecer comentários acerca de parte da produção literária contemporânea, sobretudo da prosa que narra as situações de marginalização nas grandes metrópoles do Brasil. O enfoque que pretendo oferecer a minha leitura se baseia na busca por traços de permanência de formas de representação das margens baseadas no realismo. O caminho a ser explorado alcança como ponto de ancoragem uma leitura dos textos que possibilite colocar em destaque os aspectos que evidenciam o retorno de um projeto literário que possuía como principal eixo a busca por um exame da realidade brasileira no âmbito da ficção. Por esse viés, serão tomados como objeto os textos de Ferréz, comparando-os com parte da produção literária da década de 1970, sobretudo a obra de João Antônio. A partir do estabelecimento desta proposta comparativa, será possível observar que parte do projeto literário da década de 1970 é retomado na contemporaneidade.

Ainda que o realismo seja antes de tudo uma proposta literária baseada em um desafio estético centrado na busca por artifícios que favoreçam a representação do real, ao realizar o exercício de aproximação destes dois autores, não estou propondo como único enfoque a leitura dos procedimentos estéticos adotados por ambos. Meu olhar crítico não repousa apenas no gesto realizado pelos autores na busca pela produção de um efeito de real. O movimento que pretendo realizar se baseia antes na discussão acerca do intento de produzir uma literatura amparada na representação de uma realidade social concreta a partir de um rígido discurso político. Pois, como observa Roland Barthes,

No fundo do realismo que nossa literatura conheceu, há um paradoxo notável: as relações entre o escritor e a realidade sempre foram, de fato, relações éticas, e não relações técnicas: falando-se historicamente, o realismo é uma ideia moral. (Barthes, 2004a, p. 29) 
Dessa forma, meu objetivo é perseguir a ideia moral que está subjacente ao exercício crítico de escrita destes dois autores, tratando o realismo não somente enquanto uma relação técnica com a realidade, mas, igualmente, ética.

O percurso de análise aqui proposto já foi desenhado por outros pesquisadores. Diferentes estudos sobre a literatura brasileira contemporânea já destacaram a presença de uma série de discursos centrados na representação de setores marginalizados da sociedade, como exemplo, é possível citar a leitura produzida por Tânia Pellegrini, em Despropósitos: estudos de ficção brasileira contemporânea: "Na literatura, proliferam textos já genericamente rotulados como marginais, que ancoram seu viés de revolta e denúncia num desfile de atrocidade, sevícias e escatologia" (Pellegrini, 2008, p. 177). A observação de Tânia Pellegrini é fundamentada pela leitura de três obras específicas, Cidade de Deus, de Paulo Lins; Capão pecado, de Ferréz, e Estação Carandiru, de Drauzio Varella. Segundo a crítica, estes três textos abriram

uma espécie de fresta para um mundo e sempre propositalmente ignorado, o qual, para um leitor de classe média, a imensa maioria do Brasil, além de produzir uma atração inescapável, desperta mais uma vez o terror e a piedade ancestrais. Na esteira desses êxitos editoriais, veio o enorme sucesso das adaptações cinematográficas dos dois primeiros, em 2002 e 2003, respectivamente; em seguida, os seriados da Rede Globo, Cidade dos Homens (2004), releitura de alguns temas de Cidade de Deus e, na mesma linha, Carandiru - Outras histórias (2005). (id., p. 179)

Na citação estão presentes importantes índices exploratórios para o desenvolvimento de minha reflexão. $O$ primeiro se refere ao fato de se tratarem de textos literários que se erguem a partir de um forte teor testemunhal ${ }^{4}$. Paulo Lins e Ferréz produziram seus respectivos romances com base em um frágil pacto ficcional. De modo frequente, ambos autores argumentaram que os episódios narrados no âmbito da ficção foram amplamente inspirados em fatos e eventos vivenciados nos bairros que servem

\footnotetext{
${ }^{4}$ Utilizo a expressão teor testemunhal com base na construção teórica oferecida por Márcio SeligmannSilva, no ensaio “Grande Sertão: Veredas como gesto testemunhal e confessional” (2009, p. 132-3). $\mathrm{Na}$ leitura de Seligmann-Silva, o emprego do conceito teor testemunhal busca oferecer uma leitura do texto literário que possibilite emergir atos de memória no processo de leitura crítica. No entanto, não é escusado recordar que no campo dos estudos literários já se faz presente uma corrente teórica que busca discutir, à luz da psicanálise e da filosofia, obras que se apresentam como testemunho das catástrofes do século XX, constituindo-se uma espécie de gênero literário denominado de "literatura do testemunho".
} 
de palco para a narrativa. Não é escusado lembrar que ao apresentar-se como ex-morador da favela por ele romanceada, Paulo Lins passa a ser "personagem, ator, agente que se situa naquele mesmo espaço físico, arquitetônico e simbólico de exclusão de que fala" (Resende, 2002, p. 158), como destacou com grande propriedade Beatriz Resende, em Apontamentos de crítica cultural. Leitura semelhante pode ser realizada da proposta literária de Ferréz, autor que também utiliza sua própria trajetória de vida como elemento fundante de sua produção ficcional. $\mathrm{O}$ autor, seguindo os passos de Lins, estruturou um romance ficcional centrado no cotidiano de um bairro periférico, nesse caso o Capão Redondo, localizado na zona sul de São Paulo. Se em Cidade de Deus e Capão pecado é possível identificar traços de uma escrita testemunhal, tais elementos surgem como elementos formadores do livro-reportagem Estação Carandiru, de Drauzio Varella. Dessa forma, a fresta aberta por estes livros revela não apenas aspectos de uma experiência pouco conhecida, mas, principalmente, expõe o cotidiano de espaços e sujeitos marginalizados através de uma estrutura que se quer próxima da realidade.

Recuperando a imagem da fresta, é possível dizer que a janela que os autores utilizam como ponto de observação não é nova em nossa série literária, como evidenciou Tânia Pellegrini ao afirmar que esses textos marginais despertam "mais uma vez o terror e a piedade ancestrais" (id., p. 179 , grifo meu). Por este turno, se a abordagem do cotidiano das margens urbanas favorece a volta de uma espécie de uma vertente literária, acionando um movimento que já fora operado no passado, quando o terror e a piedade foram anteriormente despertados?

Responder tal questionamento é um exercício que alcança parte significativa da literatura brasileira, passando por nomes como Orestes Barbosa, Antônio Fraga e Rubem Fonseca, para citar apenas alguns. No entanto, meu interesse não se fixa somente na observação das formas de representação da periferia na série literária brasileira. Conforme explicitado anteriormente, busco principalmente constatar os possíveis índices de permanência - ou de retorno - de traços de um modelo de representação da marginalidade urbana que se baseia na composição de um retrato da realidade. Além disso, desejo examinar quais os aspectos que, ao serem retomados, favorecem que os efeitos observados por Pellegrini - o terror e a piedade - sejam mais uma vez produzidos. Assim, a proposta de leitura em retrospecto não necessita percorrer todas as páginas de nossa literatura e pode acionar como ponto de ancoragem a década de 1970. Uma vez que será neste período que observamos a formação de uma proposta de escrita fartamente marcada pelo desejo de compor um retrato social 
da realidade brasileira, momento no qual a margem urbana - com seus personagens e temas próprios - ganha maior vulto na produção literária. No elenco dos autores do período que buscaram apresentar sua produção enquanto ferramenta de uma denúncia da condição de vida dos setores excluídos do milagre econômico, o nome de maior destaque é João Antônio. Seja pelo volume de sua obra, pelo vulto de sua fortuna crítica ou pelo papel de porta-voz do grupo, João Antônio figura como autor exemplar de um tipo de literatura que, nos dizeres de Flora Süssekind, "opta por negar-se enquanto ficção e afirmar-se como verdade" (Süssekind, 2004, p. 99). A busca pela verdade surge como uma forma de resposta aos mecanismos repressivos vigentes no período. A prosa fica ancorada ao jornalismo e o utiliza como uma espécie de modelo, atribuindo à literatura a função de relatar e retratar sujeitos/personagens em condições inenarráveis à grande imprensa.

O conto-notícia de João Antônio ou o romance-reportagem de José Louzeiro, para citar outro escritor de destaque no período, podem ser acionados como os casos mais representativos desta busca pelo realismo. Nestes, o leitor passa a travar contato direto com temas emblemáticos de uma realidade social marcada pela desigualdade. Crianças desvalidas, crimes chocantes, bandidos, malandros e prostitutas são os principais personagens de um cenário que descortina um retrato que se quer próximo da realidade. O empenho desses autores em retratar certos aspectos da sociedade brasileira, oferecendo maior destaque a um conjunto invisível de sujeitos da periferia urbana, resulta também na construção de um posicionamento político que lança mão da escrita como veículo de denúncias. No entanto, para consolidar tal experiência literária foi necessário também construir uma imagem própria para o escritor, afirmar sua dupla proximidade com o tema, "que parecia oscilar entre marginalidade semelhante à dos personagens que representava e o heroísmo de um 'Robin Hood' de classe média que se imaginava sempre ao lado 'dos fracos e oprimidos'" (id., p. 99).

No ensaio "Malditos marginais hereges", reunido no livro Escritos no Rio, Ana Cristina Cesar produz um exame semelhante acerca da postura dos escritores empenhados em retratar o povo marginalizado: "A intenção é construir a identidade de escritor com o povo a partir da própria vida do escritor (ou de dados bem selecionados dessa vida). De um escritor que, supostamente, não é consagrado, que ganha concursos, mas é esnobado ou explorado pelas editoras" (Cesar, 1993, p. 111). De forma sintética, Ana Cristina Cesar alcança uma leitura possível do ato performático realizado pelos escritores que se empenham em operar enquanto 
representantes do povo, seus porta-vozes. O exame crítico produzido por Ana Cristina Cesar tem como objeto uma coletânea de contos publicada em formato de revista e comercializada em bancas de jornal. Coordenada por João Antônio, a coletânea congrega os índices que podem ser tomados como característicos da produção literária da década de 1970, que narrava os marginais. A publicação reuniu contos de escritores como Antônio Torres, Márcio Souza, Aguinaldo Silva, Plínio Marcos, Chico Buarque, entre outros. Com uma apresentação gráfica inspirada em revistas de notícias, a publicação traz no topo a expressão "Extra", seguida da sentença: "Realidade Brasileira". No centro, em letras garrafais, temos a adjetivação dos autores: "Malditos escritores!". Para completar o jogo de inspiração com os periódicos e alardear ainda mais a busca pelo realismo factual, na capa os escritores são retratados em fotografias $3 \times 4$ com expressões sérias, remetendo claramente às imagens de presos fichados pela polícia. Na apreciação de Ana Cristina Cesar, o empenho em produzir tal efeito estético revela o desejo dos autores de enfatizar uma proximidade com o objeto narrado. Quem observa e narra as situações degradantes vivenciadas pelo povo não é um sujeito distante. Em outras palavras, o escritor maldito é apresentado enquanto um marginal, semelhante aos seus personagens, como observa a crítica:

Num golpe de mestre, ficou construída a identidade de classe entre o "nosso povo" e o "escritor típico do miserê cultural". Quem melhor para fazer literatura sobre este povo? Para narrá-lo, representálo, expressá-lo, dar-lhe voz? Se defeitos há nessa literatura, a culpa será do miserê: a rapidez do trabalho, a angústia do momento, a exiguidade geral, os dias que correm, a pobreza do nosso jornalismo, a censura, a ineficiência dos concursos, e até a falta de intimidade maior entre as pessoas e os lugares, o pouco perambular pelas ruas. São fraquezas contingentes. Haverá talento e honestidade e busca sincera do povo. (id., p. 112)

A leitura da revista revela aspectos importantes acerca do projeto literário proposto por estes escritores. É visível o uso de um tom messiânico, no qual o exercício da escrita ficcional abre espaço para uma forma de intervenção que se baseia na revelação de uma realidade social oculta. No entanto, como destacou Ana Cristina Cesar, tal realidade é observada e desvelada por um olhar solidário que busca na miséria e na marginalidade fonte de inspiração, mas não a contesta. Em outras palavras, o escritor maldito - que se quer marginal e semelhante aos personagens que povoam seus escritos - alimenta-se da miséria do outro, mas não lança um olhar crítico frente à matéria narrada. Nas palavras de Ana Cristina Cesar: 
Intenção do narrador: levar o leitor a compadecer-se das vítimas, revoltar-se contra o inimigo e os carrascos. Comover o leitor, sacudi-lo, identificá-lo à situação. Culpar e chocar, se necessário. Arrancar o leitor de suas frescuras e introduzi-lo a este mundo "mais real". (id., p. 115)

Em outras palavras, o terror e a piedade são despertados. A insistência no real, na busca pelo retrato, transforma a literatura numa espécie de espelho que reflete a desigualdade social observada pelo escritor. Ainda que a análise de Ana Cristina Cesar esteja colada na leitura da já citada revista, os apontamentos da autora podem ser utilizados como índices exploratórios da obra de João Antônio. A busca pelo exame da realidade, uma tônica constante de seus escritos, passa pela recorrente insistência em afirmarse enquanto representante dos setores marginalizados e, principalmente, pelo recorrente empenho em se vincular a este espaço marginalizado. Dessa forma, ter nascido em um bairro operário, assim como frequentar sinucas e os espaços noturnos da cidade, favorecem a formação de uma autoridade que permite ao escritor colocar-se enquanto conhecedor de um cotidiano pouco acessível. Soma-se a isto um experimento de linguagem que se quer próximo da fala dos sujeitos que habitam estes espaços marginais que servem de cenário para a narrativa. A proposta é criar uma forma de expressão literária que seja capaz de abarcar a especificidade das gírias da malandragem e, principalmente, que seja um espaço que possa abrigar as histórias e vivências de personagens que percorrem o submundo. Uma linguagem que se transforma em ato político. Um projeto que se baseia na representação da realidade social brasileira. Tal projeto ganha mais vulto quando apresentado no posfácio "Corpo-a-corpo com a vida", do livro Malhação do Judas carioca, lançado em 1975:

A desconhecida vida de nossas favelas, local onde mais se canta e mais existe um espírito comunitário; a inédita vida industrial; os nossos subúrbios escondendo quase sempre setenta e cinco por cento de nossas populações urbanas; os nossos interiores - os nossos intestinos, enfim, onde estão em nossa literatura? Em seu lugar não estarão colocados os realismos fantásticos, as semiologias translúcidas, os hipermodelismos pansexuais, os suprarrealismos hermenêuticos, os lambuzados estruturalismos processuais? Enquanto isso, os aspectos da vida brasileira estão aí, inéditos, não tocados, deixados para lá, adiados eternamente e aguardando os comunicadores, artistas e intérpretes. (Antônio, 1981, p. 146)

O trecho acima sintetiza o fazer literário de João Antônio e, principalmente, a sua crítica a uma produção literária que se revela mais preocu- 
pada com a forma do que o conteúdo. Em carta enviada em 1974 a Caio Porfírio, meses antes da publicação do posfácio "Corpo-a-corpo com a vida", João Antônio já apresenta o norte conceitual de sua busca por personagens marginalizados e por uma expressão literária marcada pelo registro do real:

Além do que tenho feito normalmente, ando muito interessado numa literatura que, fugindo ao gênero literário (essa coleira do capeta) seja menos literária e mais um corpo-a-corpo com a vida. Sei que isso já foi feito lá no estrangeiro - Vasco Patrolini, Truman Capote, Norman Mailer - , isso não me impede de várias incursões. (id., p. 49)

O abandono do gênero literário não significa o abandono das técnicas literárias. Se estabelecermos um exame da obra do autor, é possível observar, que após a publicação do posfácio "Corpo-a-corpo com a vida", João Antônio passa a produzir narrativas que se assemelham a reportagens, seguindo um modelo inspirado em Norman Mailer e Truman Capote, como o próprio autor revelou em carta. Assim, os contos passam a exibir fisionomias, sem, necessariamente, apresentar um enredo rígido em sua estrutura narrativa. $O$ personagem principal, nesse sentido, passa a ser o próprio autor que percorre os territórios multifacetados do submundo, travando contato com toda a sorte de personagens e histórias. Casa de loucos (1976), uma reunião de textos publicados em diferentes jornais, é o mais notório exemplo da nova investida de João Antônio na literatura, classificado pelo próprio como "experiências colhidas ao longo de tempos de jornalismo" (Antônio, 2004, p. 64). Com características semelhantes, Ô, Copacabana (1978) também apresenta contos-reportagens que possuem como principal personagem o bairro carioca, local em que João Antônio morou durante anos até a sua morte. Por fim, Dama do encantado, último livro inédito do autor que conta com a reunião de crônicas, contos e ensaios do autor, pode ser compreendido como ápice desse novo olhar sobre a literatura.

É interessante notar que os escritores marginais contemporâneos - ou seja, os autores ligados à Literatura Marginal ${ }^{5}$ - buscam traçar uma espé-

\footnotetext{
${ }^{5}$ Utilizo a expressão Literatura Marginal para denominar parte da produção literária contemporânea que reúne autores oriundos de bairros periféricos dos grandes centros urbanos brasileiros, principalmente de São Paulo. Este grupo de autores passou a se autointitular marginal como uma forma de caracterizar sua produção. Tal fenômeno utiliza formas de atuação claramente inspiradas em métodos de organizações sociocomunitárias, e constitui uma espécie de movimento literário, fato que provocou grande interesse por parte da crítica. Um aspecto destacado pelas pesquisas foi o ineditismo da proposta de intervenção literária, posto que estes autores são sujeitos residentes no próprio espaço
} 
cie de filiação literária com as propostas de João Antônio. Exemplar nesse sentido é a utilização de uma passagem de Abraçado ao meu rancor, de João Antônio, no prefácio "Manifesto de abertura: Literatura Marginal", assinado por Ferréz, publicado no suplemento Literatura Marginal - A cultura da periferia ATO-I, lançado pela revista Caros Amigos, e posteriormente utilizado no prefácio "Terrorismo literário", do volume Literatura marginal, talentos da escrita periférica, também organizado por Ferréz. O trecho do conto de João Antônio é citado como uma espécie de aviso aos escritores que almejam percorrer os espaços subalternizados, advertindo sobre a especificidade deste ambiente e a impossibilidade de representar tal cenário sem um mergulho na cultura e na linguagem dos sujeitos que lá residem: Evitem certos tipos, certos ambientes. Evitem a fala do povo, que vocês nem sabem onde mora e como. Não reportem o povo, que ele fede. Não contem ruas, vidas, paixões violentas. Não se metam com o restolho que vocês não veem humanidade ali. Que vocês não percebem vida ali. E vocês não sabem escrever essas coisas. Não podem sentir certas emoções, como o ouvido humano não percebe ultra-sons. (L.M. - $\mathrm{I}^{6}, \mathrm{p} .3$ )

A argumentação de João Antônio se confunde com a produzida pelos autores da Literatura Marginal: melhor representam os personagens da periferia aqueles que não apenas percorrem tais territórios, mas que possuem uma relação embrionária com estes. A equação apresentada é simples e pode facilmente ser posta em xeque - é possível apresentar uma série de autores que, mesmo não pertencentes à margem, conseguiram exprimir com qualidade tais vivências - mas tal postura, sobretudo pela sua força política, se coaduna com o principal argumento da Literatura Marginal: quem melhor representa a periferia é o periférico.

A homenagem prestada a João Antônio se estende à publicação de um texto inédito do autor em Literatura Marginal Ato II, com o título de "Convite à vida". No texto, uma carta destinada a Myltainho, o autor relata sua experiência de leitura dos romances de Machado de Assis.

Leio e releio, com calma e modos, o nosso primeiro bailarino, o safo-mor, o velho gamenho de espírito, o ferrabrás, o machucho, o bem-parido, o mais desconcertante, o elegante permanente, o mais que vitalício porque eterno Joaquim Maria Machado de Assis, o esguio de alma. (L.M. - II, p. 17)

subalternizado que serve de inspiração e tema para suas obras. Ferréz, Allan Santos da Rosa, Sérgio Vaz e Sacolinha, podem ser tomados como os principais autores do grupo.

${ }^{6}$ As citações referentes ao suplemento Literatura Marginal - A cultura da periferia, lançado pela revista Caros Amigos, utilizarei, como forma de citação, as iniciais L.M. seguidas do número do suplemento.

66 estudos de literatura brasileira contemporânea, n.39, jan./jun. 2012, p. 57-75 
O trecho publicado é seguido por uma breve apresentação do autor, na qual é oferecido destaque a sua busca por uma aproximação da "gente da periferia do capitalismo", e sintetiza: "Foi cronista das sinucas, das boates, dos malandros, das prostitutas, dos meninos de rua" (id., ibid.).

A homenagem a João Antônio não deixa dúvidas, os autores marginais contemporâneos, sobretudo Ferréz, buscam traçar uma filiação literária ao retomarem o projeto iniciado pelo autor. Repetem o mesmo gesto que João Antônio realizava em seus livros, nos quais homenageava Lima Barreto, classificando-o como o pioneiro no empenho em retratar a margem.

Ao acionar o projeto de João Antônio como referência, Ferréz elege como modelo de representação uma prosa que se fixa na busca por um retrato da realidade social brasileira. Nessa perspectiva, o autor pode ser lido como um continuador do projeto iniciado por João Antônio na década de 1970. No entanto, recuperando a imagem da espiral, é importante notar que esse movimento de retorno apresenta uma sutil diferença frente ao modelo. Em contraste ao projeto inspirador, agora a realidade social dos setores marginalizados é abordada por um sujeito oriundo do mesmo espaço subalternizado que serve de inspiração para a narrativa. A favela não é narrada por um intelectual estrangeiro, mas pelo próprio sujeito marginal. O marginalizado, enquanto excluído do lugar da produção discursiva, busca reverter a sua posição silenciosa de objeto e tornar-se sujeito do (auto)conhecimento e da escrita. Talvez seja esse aspecto extra-literário que provoca uma nova experiência do real e potencializa a recepção da obra do autor. A própria inserção de Ferréz no circuito literário foi impulsionada pela sua biografia, pelo caráter pouco usual de uma experiência literária que se origina em uma favela, como observa Érica Peçanha: "Capão pecado (...) movimentou o interesse de um periódico de grande circulação antes mesmo de ser editado" (Peçanha, 2009, p. 205). O interesse jornalístico pela publicação pode ser explicado pela forma como Ferréz apresentava seu romance, entrelaçando elementos ficcionais com eventos ocorridos na própria localidade em que residia. A matéria mencionada por Érica Peçanha foi publicada na Folha de S. Paulo, em 6 de janeiro de 2000. No texto publicado é destacado o ineditismo da obra, colocando em destaque o fato de Ferréz ter vivenciado as mesmas experiências que são narradas no texto ficcional. O próprio subtítulo da matéria coloca em evidência a convergência entre ficção e realidade: “Desempregado do Capão Redondo escreve romance baseado em histórias verdadeiras de um dos bairros mais violentos de São Paulo; livro, sem editora, está pronto, mas o autor muda trechos quando algum personagem morre na vida real". Ao ser transformado em uma espécie de obra aberta, o romance de Ferréz 
não apenas se nutre da realidade, mas é produto dessa mesma realidade. A forma como o produto discursivo é apresentado reforça o sentido documental do texto, transformando-o em um reflexo do sistema de opressão social vigente no bairro. É importante notar que foi a partir da visibilidade ofertada pela entrevista que Ferréz foi procurado pela editora Labortexto com a oferta de publicação do romance. Se o interesse pela publicação foi impulsionado pelo perfil social e engajamento político do autor, o sucesso comercial desta, que obteve uma ampla vendagem, também obedece a esse processo. Dessa forma, nos parece que esse teor testemunhal da obra, essa marca que o autor imprime nas páginas, transformando o solo ficcional em um espaço que acomoda uma narrativa claramente inspirada na realidade e que deseja se apresentar como seu possível espelho, torna o romance de estreia de Ferréz em uma obra particularmente importante para o estabelecimento de uma série de questionamentos acerca da relação entre realismo, representação da violência e vulnerabilidade social.

A representação do real passa a repousar não somente no procedimento estético adotado, mas alcança também a biografia do autor. Consciente do interesse que seu perfil pode despertar, Ferréz lança mão de uma série de artifícios que permitem a produção de um novo tratamento da realidade a partir de um olhar que se quer próximo do objeto. Um exemplo disto é a presença de dois encartes fotográficos na primeira edição do romance. Neles, o leitor passa a travar contato com uma representação imagética do cenário que é apresentado na estrutura do texto. As imagens retratam o cotidiano do bairro dando ênfase ao estado de exclusão social do bairro. Uma fotografia em especial merece a nossa atenção. Nela vê-se o autor de braços abertos, com as mãos simulando o cano de uma arma, tendo ao fundo a imagem difusa de sua comunidade. A legenda, tomada igualmente como narrativa paralela ao romance, explicita: "Me tomaram tudo, menos a rua." A rua torna-se princípio identitário, lugar que não pode ser tomado porque é também discurso de onde nascem as narrativas marginais. $\mathrm{O}$ vínculo entre rua e discurso é reafirmado, ou seja, a junção entre território e sujeito apresenta-se como uma forma de reafirmação da identidade inscrita à margem. $\mathrm{O}$ território marginal passa a ser utilizado como referência primeira para o estabelecimento de um discurso centrado na formação de uma identidade periférica.

O movimento de ligação entre sujeito autoral e território marginal realizado por Ferréz não fica restrito ao ato de fotografar-se enquanto pertencente ao mundo que busca representar. Tal princípio pode ser localizado na própria abertura do romance Capão pecado, num texto que serve como uma espécie de epígrafe, onde Ferréz cria um percurso de aproximação ao bairro em que reside, Capão Redondo: 
Universo

Galáxias

Via-láctea

Sistema solar

Planeta Terra

Continente americano

América do Sul

Brasil

São Paulo

São Paulo

Zona Sul

Santo Amaro

Capão Redondo

Bem-vindos ao fundo do mundo (Ferréz, 2000, p. 13)

O ponto de partida para alcançar o "fundo do mundo" é o mais geral possível, o universo. O objetivo não é, definitivamente, ser universal; busca-se algo específico. A trajetória traçada abre diferentes camadas, rompendo territórios. O percurso é semelhante a um jogo de escalas, com um movimento em abismo, buscando seu fim. Lendo o texto facilmente relacionamos o movimento do autor às conhecidas matrioshkas - bonecas russas que são colocadas uma dentro da outra, da maior até a menor, todas com o mesmo ornamento e cores. Mas a semelhança com o tradicional brinquedo russo é restrita ao movimento operado pelo texto, posto que não encontramos dentro da série menor uma reduplicação reduzida. A cada nova descoberta realizada pelo autor, ao romper as camadas territoriais, nos deparamos com um território em diferença. Ser o fundo do mundo, como o autor denominou o bairro em que reside e que serve de palco para a narrativa que será iniciada, não é simplesmente o ponto de chegada, mas, sim, a representação material de uma condição de extrema marginalização. O exercício de busca por uma profundidade, tal qual um fenômeno de mise en abyme realizado por Ferréz, afirma a territorialidade do texto em duas perspectivas: primeiro enquanto cenário do romance, focando o Capão Redondo, bairro da periferia da Zona Sul de São Paulo, como espaço em que será representado o texto ficcional; e, na segunda possibilidade de análise, afirma o território em um sentido político, apresentando o romance enquanto produto discursivo originário do "fundo do mundo" - espaço marginalizado por excelência, na leitura do autor. Capão Redondo passa a ser o elemento final a ser descortinado por um olhar em profundidade lançado por um sujeito marginal.

O romance de Ferréz busca reunir os principais elementos formadores 
de um retrato da periferia urbana. Ao longo do texto, através de Rael, o protagonista da narrativa, travamos contato com os diferentes tipos sociais da favela: o jovem empenhado na melhoria da vida pelo trabalho, o assaltante temido pela violência de seus atos, o nordestino desempregado e alcoólatra, a doméstica negra explorada pela patroa branca, o pastor evangélico e o jovem desempregado e alienado. Tais sujeitos são expostos no texto segundo um rígido maniqueísmo, no qual não sobram críticas pontuais acerca das posturas concebidas como errôneas - como o consumo de drogas, a prática de assaltos, o alcoolismo e a alienação política - e, na mesma lógica, os personagens que trilham caminhos que são facilmente lidos como exemplares são emoldurados a partir de um tom exultante de suas ações - a assiduidade ao trabalho, o envolvimento em ações de cunho social e comunitário e a presença na rotina escolar.

Tá certo, ce vê o Alaor tá na correria, o Panetone e o Amaral também tão dando mó trampo, mas o resto, mano, na moral, tão vacilando. Eles tinham que ouvir as ideias do Thaíde, tá ligado? "Sou pobre, mas não sou fracassado". Falta algo pra esses manos, sei lá, preparo; eles têm que se ligá, pois se você for notar, tudo tá evoluindo e os chegado tão lá no mesmo, e não tô dizendo isso porque sou melhor não. Ce tá ligado que comigo isso não existe, mas na moral, cara, esses aí vão ser engolidos pelo sistema; enquanto eles dormem até meio-dia e fica rebolando nos salão até de manhã, os playbas estão estudando, evoluindo, fazendo cursinho de tudo que é coisa. (id., p. 117)

Além da presença visível de uma grafia própria das palavras e da tentativa de transpor para a escrita um discurso formado pela oralidade, principalmente pelo uso de gíria, o trecho acima evidencia o caráter pedagógico da escrita de Ferréz. O próprio enredo da história é construído a partir da oposição descrita no trecho recolhido. Rael, o protagonista do romance, é descrito como um jovem regrado, trabalhador e empenhado na sua melhora de vida. Este deposita no trabalho e na educação formal a possibilidade de ascensão social. A leitura salvacionista da educação, conceituação amplamente criticada pelas correntes mais progressistas no âmbito acadêmico, surge na prosa de Ferréz como a única saída possível para a consolidação de um sonho de progresso de vida pessoal e coletiva.

Condensada em pouco mais de 170 páginas temos a tentativa de retratar uma realidade marcada pela vulnerabilidade social, violência e miséria, resultando em uma imagem que se revela mais fiel à percepção do autor sobre seu próprio território do que um dado realista sobre esse. Pois, 
é através da mão de Ferréz, que filtra, hierarquiza e julga, que travamos contato com o Capão Redondo e bairros adjacentes.

Tal forma de representação da periferia, subordinada a um desejo de agenciamento político através da literatura, também é facilmente encontrada no conto "Tentação", de Alessandro Buzo, escritor e militante do movimento Hip-hop, que igualmente pode ser caracterizado como um autor marginal. No conto, a narrativa é iniciada com a descrição de uma cena: "Na roda da fogueira que nunca cresce e nunca se apaga estão Matraca, Coelho e Cezinha, eles comentam com saudades sobre Júnior..." (Buzo, 2005a, p. 105). Após essa descrição, utilizando uma narração em flashback, a narrativa concentra-se na trajetória do personagem que é rememorada pelos amigos. A história de Júnior é tratada de forma linear, mas há o efeito de suspensão, provocado pela cena descrita na abertura do conto. Dessa forma, acompanhamos a trajetória do personagem questionando quando será relatada a sua morte. É com tal premissa que o narrador enumera, sem se estender, os principais aspectos da infância e adolescência do personagem:

Foi uma criança comum de favela, que corre descalça por ruas de terra, que solta pipa, brincou de pião, bolinha de gude, escondeesconde e os primeiros beijos numa garota foi brincando de beijo, abraço ou aperto de mão. O Tijuco Preto até hoje em pleno 2004 tem sua rua principal sem asfalto. (id., ibid.)

Mesmo que de forma simplificada, a articulação entre ficção e realidade favorece a criação de uma forma de agenciamento. Ao apresentar o cenário do conto em sua materialidade contemporânea, dado sem relevância para a economia da narrativa, o autor aponta para a necessidade de recriação de um olhar para as condições físicas da periferia. Narrase não apenas a ficção de um jovem de uma favela, mas a historicidade de todo um espaço marginalizado. Nesse sentido, a própria trajetória do personagem confunde-se com a de outros sujeitos. A afirmação da ausência de um dado intrínseco ao personagem, pois é descrito como "uma criança comum da favela", torna a história privada do personagem uma história coletiva. Deleuze, no ensaio "Literatura e vida", apresenta uma definição do fazer literário das minorias que é útil para a análise que realizo: "Embora remeta a agente singulares, a literatura é agenciamento coletivo de enunciação" (Deleuze, 1997, p. 14-5). É com esse tom coletivo que o narrador aponta os elementos constituintes da opção do jovem pelo tráfico de drogas: "Como estava com dezessete anos não conseguiu emprego nenhum, a fase do Exército quebra as pernas de vários jovens" (Buzo, 2005a, p. 106, grifo meu). O desfecho, por sua reincidência, seja na ficção 
ou na realidade, é conhecido: sem dinheiro e sem oportunidades seguras, o personagem passa a assaltar e atuar como varejista do comércio de drogas, acabando morto ainda adolescente pela polícia. Fechando o conto, o narrador retoma a imagem apresentada na abertura: "Na rodinha em volta da fogueira todos lembram dele com saudades e são unânimes, ele não era do crime, caiu em tentação" (id., p. 107). A sentença que fecha o conto é claramente amparada nos discursos religiosos e apresenta o personagem como um exemplo, tornando a própria narrativa uma espécie de história de proveito e exemplo. $\mathrm{O}$ tom pedagógico empregado pelo autor não deixa dúvidas, trilhar o caminho do crime aponta para uma única saída: a morte. Por esse viés, a literatura surge como veículo para a propagação de uma orientação política dos sujeitos. Ao fixar-se em um modelo de representação baseado no realismo, o discurso literário passa a reunir os elementos possíveis para a realização desse objetivo.

Assim, a insistência em uma prosa calcada no real obedece primeiramente ao projeto de literatura que se origina nas periferias. Posto que não se trata somente de ter voz própria, mas de estabelecer essa voz como meio de expressão coletiva, utilizando para tanto um espaço do qual esses grupos foram, quase sempre, excluídos: a literatura. A realidade da periferia não surge apenas como inspiração, mas, igualmente, como algo a ser enfrentado. Por outro lado, a adoção do realismo pelas mãos de um autor que se apresenta como sujeito pertencente ao mesmo espaço de exclusão que ficcionaliza também desperta o interesse dos leitores não familiarizados com essa realidade. A possibilidade de conhecer os setores marginais da sociedade pelo ponto de vista de dentro, sem mediação, impulsiona o sucesso editorial de algumas obras e a visibilidade dos autores. Dessa forma, ainda que seja resultante de um projeto literário ligado a uma postura política própria, o discurso desses autores passa a engrossar um amplo espectro de narrativas, filmes e documentários que igualmente retratam a realidade da violência urbana no Brasil contemporâneo, como observa Beatriz Jaguaribe:

O "boom" de biografias, livros de reportagem, documentários, filmes e narrativas realistas não é uma novidade para o público brasileiro, mas o que marca a produção recente é o forte apelo ao retrato da realidade em face da violência. Favelas, centros correcionais, periferias urbanas carcomidas, prisões infectadas e a saga de traficantes são alguns dos tópicos abordados. A despeito da variedade de códigos e registros, esses relatos ficcionais e documentais realistas constituem também uma resposta às fabricações televisivas do "real". (Jaguaribe, 2007, p. 110) 
Não se trata de elaborar uma exasperada crítica dos meios de comunicação de massa e das grandes corporações editoriais que promovem tais discursos, mas compreender tal fenômeno cultural e comercial como um substrato da própria sociedade brasileira. A margem, este território quase esquecido e muitas vezes invisível da cidade, surge na contemporaneidade como um precioso território a ser explorado. Seja pelo olhar do próprio marginal ou por autores não pertencentes à margem que são movidos pelo crescente interesse do mercado editorial, é inegável que a periferia urbana ocupa hoje, paradoxalmente, um espaço central na produção discursiva brasileira.

\section{Referências bibliográficas}

ANTÔNIO, João (1981). Malhação do Judas carioca. Rio de Janeiro: Record. (1982). Malagueta, perus e bacanaço. Rio de Janeiro: Record.

(1994). Casa de loucos. Rio de Janeiro: Rocco.

(1996). Dama do Encantado. São Paulo: Nova Alexandria.

(2001a). Abraçado ao meu rancor. São Paulo: Cosac \& Naify.

(2001b). Ô, Copacabana. São Paulo: Cosac \& Naify.

(2004). Cartas aos amigos Caio Porfírio e Fábio Lucas. Cotia/São Paulo: Oficina do Livro Rubens Borba de Moraes/Ateliê.

BARTHES, Roland (2004a). “Novos problemas do realismo". In: Inéditos I - Teoria. São Paulo: Martins Fontes.

tins Fontes.

(2004b). "O efeito do real". In: O rumor da língua. São Paulo: Mar-

BUZO, Alessandro (2005a). “Tentação”. In: FERRÉZ (Org.). Literatura marginal: talentos da escrita periférica. Rio de Janeiro: Agir.

(2005b). "Toda brisa tem o seu dia de ventania". In: FERRÉZ (Org.). Literatura marginal: talentos da escrita periférica. Rio de Janeiro: Agir.

CESAR, Ana Cristina (1993). “Malditos escritores hereges”. In: Escritos no Rio. Rio de Janeiro: Editora UFRJ/Editora Brasiliense.

DELEUZE, Gilles (1997). “A literatura e a vida”. In: . Crítica e clínica. São Paulo: Editora 34.

FERRÉZ (2000). Capão pecado. São Paulo: Labortexto Editorial.

(Org.) (2001). Caros Amigos/Literatura marginal: a cultura da periferia - Ato I. São Paulo. ago.

(Org.) (2002). Caros Amigos/Literatura marginal: a cultura da periferia - Ato II. São Paulo. jun. neiro: Agir.

(Org.) (2005). Literatura marginal: talentos da escrita periférica. Rio de Ja- 
FIGUEIREDO, Vera Lúcia Follain de (2010). “Novos realismos, novos ilusionismos". In: _. Narrativas migrantes: literatura, roteiro e cinema. Rio de Janeiro: PUC-Rio/7 Letras.

JAGUARIBE, Beatriz (2007). O choque do real: estética, mídia e cultura. Rio de Janeiro: Rocco.

(2010). "Ficções do real: notas sobre as estéticas do realismo e pedagogias do olhar na América Latina contemporânea". Ciberlegenda. Niterói. v. 2, n. 23, p. 6-14.

LINS, Paulo (1997). Cidade de Deus. São Paulo: Companhia das Letras.

MARX, Karl (1997). O 18 de Brumário e cartas de Kugelmann. 7. ed. Rio de Janeiro: Paz e Terra.

PELLEGRINI, Tânia (2008). Despropósitos: estudos de ficção brasileira contemporânea. São Paulo: Annablume/Fapesp.

PEÇANHA, Érica (2009). Vozes marginais na literatura. Rio de Janeiro: Aeroplano. RESENDE, Beatriz (2002). Apontamentos de crítica cultural. Rio de Janeiro: Aeroplano. SELIGMANN-SILVA, Márcio (2009). “Grande Sertão: Veredas como gesto testemunhal e confessional". Alea. v. 11, n. 1, p. 130-47, jan./jul.

SCHØLLHAMMER, Karl Erik (2009). Fiç̧ão brasileira contemporânea. Rio de Janeiro: Civilização Brasileira.

SÜSSEKIND, Flora (1984). Tal Brasil, qual romance?- Uma ideologia estética e sua história: o naturalismo. Rio de Janeiro: Achiamé.

(2004). Literatura e vida literária: polêmicas, diários e retratos. Belo Horizonte: Editora UFMG.

VARELLA, Draúzio (1999). Estação Carandiru. São Paulo: Companhia das Letras.

Recebido em agosto de 2011.

Aprovado em outubro de 2011.

\section{resumolabstract}

\section{A volta da realidade das margens}

Paulo Roberto Tonani do Patrocínio

O presente artigo busca discutir a permanência de formas de representação da periferia urbana que se baseiam no Realismo. É com esta orientação que proponho tecer comentários acerca de parte da produção literária contemporânea, sobretudo da prosa que narra as situações de marginalização nas grandes metrópoles do Brasil. O caminho a ser explorado alcança como ponto de ancoragem uma leitura dos textos contemporâneos que possibilite colocar em destaque os aspectos que evidenciam o retorno de um projeto literário que possui como principal eixo a busca por um exame da realidade brasileira no âmbito da ficção. 
Palavras-chave: literatura brasileira contemporânea, realidade social, marginalidade, literatura marginal, representação

\section{The return of periphery's reality}

Paulo Roberto Tonani do Patrocínio

This article discusses the persistence of forms of representation of the urban periphery that are based on realism. It is with this approach that I propose to comment on some of the contemporary literary production, especially prose that describes marginalizing situations in Brazil's big cities. The path explored is anchored in the reading of contemporary texts that highlight aspects that establish the return of a literary project that has the search for a review of Brazilian reality within fiction as its main axis.

Key words: contemporary brazilian literature, social reality, marginality, marginal literature, representation 